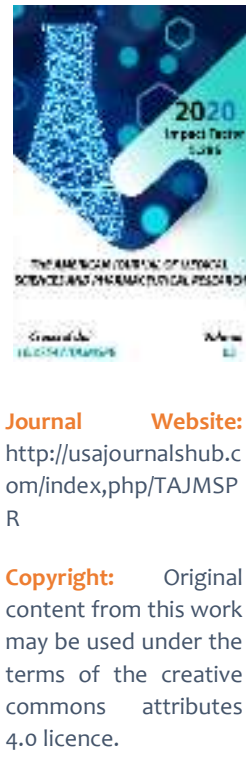

\title{
Occurrence Features Hemangiomas Integument In Preterm Children
}

\author{
Karimkulov Nodirbek Abdujalilovich, \\ Andijan State Medical Institute, Andijan, Uzbekistan \\ Sadykov Rasul Rustamovich \\ Tashkent Medical Academy, Department Of Surgical Diseases, Uzbekistan
}

\section{ABSTRACT}

Premature pregnancy is one of the factors in the occurrence of hemangiomas in newborns. Retrospective analysis of data from case histories and outpatient cards of the surgery department of 1 city hospital and polyclinics in Tashkent for 2015-2017. Depending on the pregnancy, premature babies with skin and soft tissue hemangiomas were divided into 3 groups: 1st group $(n=11)$ - with a gestation period of 27-30 weeks; Group $2(n=14)$ - with a gestation period of 31-33 weeks; 3rd group $(n=8)$ - with gestational age 34-36 weeks. The children were also distributed depending on weight: with a body weight of less than 1000 grams - 1st subgroup $(n=7)$, with a body weight from 1000 to 1500 grams - 2nd subgroup $(n=6)$, with body weight from 1500 to 2000 grams - 3rd subgroup $(n=9)$, with body weight over 2000 grams - 4th subgroup $(n=11)$. We found that the incidence of hemangiomas in premature babies depends on the duration of pregnancy and body weight at birth. The risk factors for the occurrence of hemangiomas of the skin and soft tissues in premature babies are the gestation period of less than 30 weeks. and extremely low birth weight.

\section{KEYWORDS}

Premature babies, hemangioma, benign vascular tumors 


\section{INTRODUCTION}

Benign vascular tumors (BVT) are the most common and poorly studied form of vascular anomaly (VA) and are observed in 5-10\% of all newborns. The incidence of hemangiomas in children aged 1-year increases to $10-12 \%[2,4,7$, 10]. Moreover, in girls, hemangiomas occur 3-7 times more often than in boys [4-6, 11]. Due to the high urbanization and the general deterioration of the ecological state of the environment, the frequency of occurrence of BVT tends to increase. BVTs are more often manifested in children at the age of 2 weeks after birth, characterized by extremely rapid growth and invasion of the surrounding tissues $[1,5,7,8]$. The reasons for the development of BVT remain unclear. Contributing factors can be toxicosis of pregnant women, prematurity of the fetus, heredity, etc., which can be observed in almost every woman in labor [10, 11], which significantly complicates the solution of the problem. At the present time, an important and not yet studied problem of VA is the identification of demographic characteristics and risk factors in the population of different regions. In connection with the deterioration of the environment, there is a tendency towards an increase in the VA frequency. The issues of predicting the course of vascular tumors remain relevant, in connection with which molecular genetic studies are carried out, a search for more informative non-invasive diagnostic methods is carried out. Among the many risk factors, the most interesting are: prematurity and fetal malnutrition, placental insufficiency (placenta previa, placental abruption, preeclampsia, placentitis), problems of carrying a pregnancy with drug preservation, intracavitary invasive diagnostic interventions (biopsy of maternal pregnancy), multiple over 35 years), pregnancy after in vitro fertilization, frequent colds, taking hormonal drugs. [4-11]. The summary results of assessing the causes of BVT showed a high correlation between the appearance of BVT in parents who took contraceptives and in the presence of hereditary diseases. Anemia during pregnancy, multiple pregnancies, etc. are also predisposing factors for the development of BVT. According to world statistics, among $15 \%$ of premature newborns (50,000 children), single or multiple hemangiomas were detected, in the group of newborns weighing from 3000 to 3500 , the risk of hemangiomas increased by $29 \%$ for every $500 \mathrm{~g}$ of weight deficit [12] Among premature infants weighing less than $1000 \mathrm{~g}$, hemangiomas are found in $20-22 \%$ of children $[6,9-11]$. Thus, the problem of studying the incidence of hemangiomas of the skin and soft tissues in premature infants is urgent.

The aim of the study is to reveal the dependence of the incidence of hemangiomas of the skin and soft tissues in premature infants depending on their gestational age and birth weight.

\section{MATERIAL AND RESEARCH METHODS}

The work was performed in the course of Grant topics at the departments of GP surgery of the Tashkent Medical Academy and Pediatric Oral and Maxillofacial Surgery of the Tashkent State Dental Institute, as well as at the Central Research Laboratory of TMA and the clinical base of the State Clinical Hospital No. 1 for 20152017. All premature babies (PB) were distributed according to age (infancy) (Table 1) and birth weight (Table 2).

Static studies were performed according to standard clinical guidelines. Quantitative data are presented as arithmetic mean (M) \pm standard deviation (SD) for normal 
distributions and as median (Md) and quartiles (Q) or (SD) for other distributions. The significance of differences was determined by the Student's t-test. Differences were considered statistically significant at $\mathrm{p}<0.05$.

The first stage of statistical processing was carried out using the MS Excel computer program, into which the formulas for calculating the ranges of values of the studied indicators in the observation groups, adopted in biomedical statistics, were entered. The second block of the sequence of statistical data analysis was supported by the SystatSoftware (USA) and MedCalc (Belgium) software package according to the requirements for medical data analysis.

Table 1. Distribution of premature babies by gestational age for the period 2015-2017

\begin{tabular}{|c|c|c|c|c|}
\hline \multirow{2}{*}{$\begin{array}{c}\text { Premature } \\
\text { children Years }\end{array}$} & \multicolumn{4}{|c|}{ Years } \\
\hline & $\begin{array}{c}2015 \\
(n=262)\end{array}$ & $\begin{array}{c}2016 \\
(n=275)\end{array}$ & $\begin{array}{c}2017 \\
(n=178)\end{array}$ & $\begin{array}{l}2015-2017 \\
(n=715)\end{array}$ \\
\hline $\begin{array}{l}\text { PB weighing less than } 1000 \mathrm{~g} \\
\text { (abs.) }\end{array}$ & 22 & 24 & 14 & 60 \\
\hline $\begin{array}{l}\text { PB with bodyweight 1000-1500 g } \\
\text { (abs.) }\end{array}$ & 39 & 57 & 34 & 130 \\
\hline $\begin{array}{l}\text { PB with a bodyweight of 1500- } \\
2000 \mathrm{~g} \text { (abs.) }\end{array}$ & 96 & 99 & 67 & 262 \\
\hline $\begin{array}{c}\text { PB weighing more than } 2000 \\
\text { (abs.) }\end{array}$ & 105 & 95 & 63 & 263 \\
\hline
\end{tabular}


Table 2. Distribution of premature babies depending on body weight at birth for the period 2015-2017

\begin{tabular}{|c|c|c|c|c|}
\hline \multirow{2}{*}{$\begin{array}{c}\text { Premature } \\
\text { children }\end{array}$} & $\begin{array}{c}|c| \\
2015 \\
(\mathrm{n}=241)\end{array}$ & $\begin{array}{c}2016 \\
(\mathrm{n}=258)\end{array}$ & $\begin{array}{c}2017 \\
(\mathrm{n}=166)\end{array}$ & $\begin{array}{c}2015-2017 \\
(\mathrm{n}=665)\end{array}$ \\
\hline $\begin{array}{c}\text { Gestational age 27-30 weeks. } \\
\text { (abs.) }\end{array}$ & 66 & 56 & 34 & 156 \\
\hline $\begin{array}{c}\text { Gestational age 31-33 weeks. } \\
\text { (abs.) }\end{array}$ & 70 & 93 & 60 & 223 \\
\hline $\begin{array}{c}\text { Gestational age 34-36 weeks. } \\
\text { (abs.) }\end{array}$ & 105 & 105 & 72 & 282 \\
\hline $\begin{array}{c}\text { Premature } \\
\text { children }\end{array}$ & 2013 & 2014 & $\begin{array}{c}2015 \\
(\mathrm{n}=166)\end{array}$ & $2013-2015$ \\
$(\mathrm{n}=665)$
\end{tabular}

\section{RESEARCH RESULTS}

All premature infants with hemangiomas of the skin and soft tissues $(n=33)$ were divided into three groups depending on age: group $1(n=11)$ - PB with a gestational age of 27-30 weeks; 2nd group ( $n=14)$ - PB with a period of 31-33 weeks; Group $3(n=8)$ - PB with a period of 34-36 weeks; in newborns with a birth age of 37 weeks. hemangiomas did not occur in the first 2 months of the child's life, so they were not included in the study group. Distribution of premature infants with skin hemangiomas by years for the period 2015-2017 depending on 
the age (1st, 2nd, 3 rd group) is presented in the table. 3 .

Table 3. The incidence of hemangiomas in premature babies, depending on gestational age for the period 2015-2017.

\begin{tabular}{|c|c|c|c|c|}
\hline \multirow{2}{*}{ Groups } & \multicolumn{4}{|c|}{ Years } \\
\cline { 2 - 5 } & 2015 & 2016 & 2017 & $2015-2017$ \\
\hline 1st group & $6(9,1 \%)$ & $1(1,8 \%)$ & $4(11,7 \%)$ & $11(7,5 \%)$ \\
\hline 2nd group & $4(5,7 \%)$ & $3(3,2 \%)$ & $7(11,7 \%)$ & $14(6,3 \%)$ \\
\hline 3rd group & $2(1,9 \%)$ & $6(5,7 \%)$ & $0(0 \%)$ & $8(2,8 \% * \#)$ \\
\hline
\end{tabular}

\# - reliability of differences between groups 2 and 3 ( $p<0.05)$

Note: * the reliability of differences between the 1st and 3 rd groups $(p<0.05)$

When calculating the average incidence of hemangiomas of the skin in premature infants in each of the groups, it was found that the highest numbers were noted in the 1st group and the lowest in the 3 rd group. Thus, the incidence of hemangiomas in premature infants with a gestational age of 27-30 weeks. was 2.7 times higher than in premature babies with a gestational age of 34-36 weeks. Thus, the highest incidence of hemangiomas was observed in children with the lowest age at birth. Therefore, one of the risk factors for hemangiomas of the skin in premature infants is the age at birth less than 30 weeks.

Of the 33 examined premature infants with skin hemangiomas, 14 were boys, which corresponded to $42.4 \%, 19$ children were girls, which corresponded to $57.6 \%$. The results obtained in the course of the study once again confirm the literature data $[3,5,7,11,18]$ about the greater occurrence among girls with hemangiomas of the skin, including in premature babies.
Further, premature infants with hemangiomas of the skin were examined depending on the body weight at birth (Table 2). The statistical analysis included premature babies only with hemangiomas of the skin with a birth weight of fewer than 1000 grams - 1st subgroup $(n=7)$, with a bodyweight of 1000 to 1500 grams - 2nd subgroup $(n=6)$, with a weight body from 1500 to 2000 grams - 3 rd subgroup $(n=9)$, with bodyweight over 2000 grams - 4th subgroup ( $n$ = 11) (Table 4).

In a statistical analysis of the average incidence of hemangiomas of the skin and soft tissues in premature infants in each of the subgroups, it was found that the highest numbers were observed in the 1st subgroup and the lowest in the $3 \mathrm{rd}$ and 4 th subgroups. Consequently, the highest incidence of hemangiomas was observed in children with extremely low birth weight (less than 1000 grams), and was 2.76 times higher than in premature babies weighing more than 2000 grams. 
The results obtained confirm the conclusion about the high incidence of hemangiomas in children with low birth weight. Prematurity, and, therefore, low birth weight is one of the predisposing factors in the occurrence of skin hemangiomas in children. The risk of skin hemangiomas in children born prematurely is much higher than in those born on time. Moreover, if the incidence of hemangiomas in children at birth and the first months of life is 2$10 \%$, then among premature infants weighing less than $1000 \mathrm{~g}$, hemangiomas are found in 20$22 \%$ of children[2, 4, 6, 7, 9, 12$]$.

Table 4. Distribution of premature infants with skin hemangiomas by subgroups depending on body weight at birth

\begin{tabular}{|c|c|c|c|c|}
\hline \multirow{2}{*}{ Subgroups } & \multicolumn{4}{|c|}{ Premature babies } \\
\hline & 2015 & 2016 & 2017 & $2015-2017$ \\
\hline 1st subgroup & ${ }_{(13,6 \%)}^{3}$ & $0(0 \%)$ & $\begin{array}{r}4 \\
(28,6 \%)\end{array}$ & $7(11,6 \%)$ \\
\hline 2nd subgroup & $\begin{array}{ll} & 2 \\
(5,1 \%)^{2} & \end{array}$ & $\begin{array}{rr} & 1 \\
(1,8 \%) & \end{array}$ & $(8,8 \%)^{3}$ & $6(4,6 \%)$ \\
\hline 3rd subgroup & $\begin{array}{r}4 \\
(4,7 \%)\end{array}$ & ${ }_{(3,0 \%)}^{3}$ & ${ }_{(2,9 \%)}^{2}$ & $9(3,4 \% \#)$ \\
\hline 4th subgroup & ${ }_{(2,9 \%)^{3}}^{3}$ & $\begin{array}{r}6 \\
(6,3 \%)\end{array}$ & $(3,2 \%)^{2}$ & $\begin{array}{l}\text { ж } \\
11(4,2 \%)\end{array}$ \\
\hline
\end{tabular}

Note: * - reliability of differences between the 1st and 4th subgroups ( $p<0.05)$;

\# - reliability of differences between 1st and 2nd subgroups $(p<0.05)$ \# -

Reliability of differences between 1 st and 3 rd subgroups $(p<0.05)$

Indicators often used in practice, such as age and body weight, do not reflect the essence of the emerging pathological conditions and are only indirect witnesses of possible disorders in the body of a newborn [1]. That is, early childbirth and low birth weight is only one of the predisposing factors for the occurrence of hemangiomas. The lower the age at birth and the lower the bodyweight of the newborn, the more significant the causes of miscarriage, which in turn affects the formation of various 
pathologies in the child, including vascular [411].

\section{CONCLUSION}

Thus, the incidence of hemangiomas in premature infants depends on the age of the child at birth and body weight at birth. At the same time, the risk factors for the occurrence of hemangiomas of the skin in premature infants are less than 30 weeks of age and extremely low birth weight.

\section{REFERENCES}

1. Akbarov AA, Dusmukhamedov $M Z$, Boltakhodzhaeva Experience in the treatment of hemangiomas of the maxillofacial region in children // Dentistry of children and prevention: a peerreviewed scientific journal recommended by the Higher Attestation Commission. 2010. - T.9, No. 2. - S. 43-46.

2. Altman IV Vascular anomalies as a consequence of impaired embryonic angiogenesis // Clinical embryology. 2008. - Vol. 1, No. 1. - S. 46-48.

3. Barannik M.I. Problems and errors of percutaneous laser coagulation of skin vessels in the practice of a dermatocosmetologist // Plastic surgery and cosmetology. - 2011. - No. 2. - S. 335347.

4. Barannik M.I., Belyanina E.O. Errors and complications when using various methods of removing benign skin neoplasms. Stationary replacement technologies // Outpatient surgery. - 2008. - No. 2 (30). - S. 19-27.

5. Barannik M.I., Belyanina E.O. Problems and errors of percutaneous laser coagulation of skin vessels in the practice of a dermatocosmetologist // Plastic surgery and cosmetology. - 2011. - No. 2. S. 335-347.

6. Belysheva T.S. Laser therapy of vascular skin formations in children // Sarcomas of bones, soft tissues, and skin tumors. - 2011. - No. 3. - S. 37-47.

7. Berezhnova S.G. Combined conservative treatment of hemangiomorbital and periorbital areas in young children: Dis ... cand. medical sciences. - M., 2014 -- 112 p.

8. Berezhnova S.G. The main directions of treatment of hemangiomas of orbital and periorbital localization in children // Russian Ophthalmological Journal. - 2013. - T.6, No. 1. - S. 96-102.

9. Bleskin B.I., Klyukin L.M., Mikheev S.V. The use of contact thermography for early rapid diagnosis of type 1 diabetes mellitus and monitoring of its treatment // Med technic. - 2010. - No. 5. - S. 25-26.

10. Butov YS, Akhtyamov SN Possibilities of electrosurgery in dermatology // In the book: Dermatovenereology: national guidance. / Ed. Yu.K. Skripkina, Yu.S. Butova, O. L. Ivanova. - M :: GEOTARMedia, 2011. - S. 222-231.

11. Butorina A.V., Shafranov V.V., Polyaev Yu.A., Tsyganov D.I. Modern treatment of hemangiomas in children. Advanced technologies at the turn of the century. Moscow: "Elekta-Print", 2000. - pp. 355 361.

12. Vozdvizhensky IS, Butorina AV, Shafranov VV Laser photo-coagulation of capillary angiodysplasias of the skin in children // Conference proceedings: Present and future of pediatric surgery. - Moscow, 2001 .- S. 55-56.

13. Vasiliev I.S., Abushkin I.A., Diomidov I.A. Vascular anomalies: terminology, 
classification // Bulletin of SUSU. Series: Education, health care, physical education. - 2013. - T. 13, No. 3. - S. 66-68.

14. Volodin N.N. Neonatology: a national guide. - Moscow, 2009 .-- 848 p.

15. Wolf K. Fitzpatrick's Dermatology in Clinical Practice: in 3 volumes - $M$.: Panfilov Publishing House, Binom. - 2012. -T.2. - S. 1270-77. 